\title{
FURTHER OBSERVATIONS OF ALBINISM IN BIRDS
}

JEAN BANCROFT, 306 - 200 Tuxedo Boulevard, Winnipeg, Manitoba. R3P OR3

Since my last publication, there have been several additional reports in Blue Jay regarding albinism in birds (Table 1). ${ }^{1}$

During the summer and fall of 1991, Miles Constable observed "a grey and white-coloured version" of a magpie in central Edmonton, Alberta. $^{2}$

Daisy Meyers of Leader, Saskatchewan, sighted a very pale grey American Crow in a large flock of the usual black crows, 27 August $1991{ }^{3}$ She also saw an albino Canada Goose grazing on her ranch, 1 June 1981 , in a flock of 20 normal Canadas. ${ }^{3}$ On several occasions a partial albino Ring-necked Pheasant appeared on her ranch, but she did not keep note of the dates. ${ }^{3}$

In September 1991, Therese Ethier of Hoey, Saskatchewan, ob- served a Brewer's Blackbird with an all-white head (pers. comm.).

On 11 September 1992, Frances Vyse reported the sighting of a white crow in Kamloops, British Columbia, for nearly a year. ${ }^{6}$

In January 1990, Elaine Radwanski of Archerwill, Saskatchewan, spotted a white-headed redpoll in a flock of Common and Hoary Redpolls. ${ }^{4}$

Ernie Taylor of Grand Marais, Manitoba, noticed a partial albino American Robin beside a bird bath in his yard in October 1992 (pers. comm.). Half of the bird's back feathers were white and about a third of the upper part of its breast was white.

Ivey and Norma Simmons of Kerrville, Texas, on 29 January 1992

\section{Table 1. ALBINO BIRD SIGHTINGS}

\begin{tabular}{|l|c|}
\hline \multicolumn{1}{|c|}{ Species } & No. of records \\
\hline American Crow & 2 \\
\hline Black-billed Magpie & 1 \\
\hline Canada Goose & 1 \\
\hline Ring-necked Pheasant & 1 \\
\hline Redpoll & 1 \\
\hline American Robin & 2 \\
\hline Double-crested Cormorant & 1 \\
\hline Dark-eyed Junco & 1 \\
\hline White-throated Sparrow & 1 \\
\hline Brewer's Blackbird & 1 \\
\hline Ten species & 12 records \\
\hline
\end{tabular}


sighted an American Robin which was all white except for its red breast. $^{5}$

In the fall of 1991 John Dennis of Maryland observed an albino Double-crested Cormorant in Outer Banks, North Carolina.

A report by Peter Whelan mentioned that two albinos had appeared at a Nova Scotia feeder - a Darkeyed Junco in early April 1992, and a White-throated Sparrow "earlier in the winter [1991]" (pers. comm.).

1. BANCROFT, J. 1991. Observations of albinism in birds. Blue Jay 49:139140.
2. CONSTABLE, M. 1991. Albino magpie near Edmonton. Blue Jay 50:125.

3. MEYERS, D. 1991. More albino birds. Blue Jay 50:62-63.

4. RADWANSKI, E. 1990. White-headed redpoll near Archerwill, Saskatchewan. Blue Jay 49:141.

5. SIMMONS, I. and N. Simmons. 1992. Saw an albino robin. Nature Society News. March 1992. p. 8.

6. VYSE, F. 1992. White crow sighted, Kamloops, British Columbia. Winnipeg Free Press, 11 September 1992.

7. WHELAN, P. 1992. The birding bonuses of a cold April day. Globe and Mail, 18 April 1992.

\section{SOME ALBINO BIRDS FROM AVONLEA}

FLOSSIE BOGDAN, Box 207, Avonlea, Saskatchewan. SOH 0C0

22 and 23 September 1991: A white sparrow was observed from my kitchen window. It had some brown on tips of wings and at end of tail, black head stripes and yellow lores. The yellow lores helped to identify it as a partial albino Whitethroated Sparrow (see illustration).

20 September 1990: A partial albino starling on the power line. It was being fed (along with two young starlings) by an adult starling (see illustration).

The power lines are all underground now. In the fall we miss seeing the 200 to 300 swallows all lined up like clothes pins on the lines.

In 1985, we saw an albino grackle. It was a very wary bird. We could only observe it from the window of the trailer as it fed on crumbs on the picnic table. 